\title{
Salience and the emergence of international norms: Napalm and cluster munitions in the inhumane weapons convention
}

\author{
Elvira Rosert* \\ Universität Hamburg and Institute for Peace Research and Security Policy \\ ${ }^{\star}$ Corresponding author. Email: elvira.rosert@uni-hamburg.de
}

(Received 28 August 2017; revised 18 June 2018; accepted 19 June 2018; first published online 22 August 2018)

\begin{abstract}
This article theorises salience - defined as the amount of attention granted to an issue - as an explanatory factor for the emergence and non-emergence of norms, and shows how salience affects existing explanations such as issue adoption by norm entrepreneurs, mobilisation, social pressure, and framing. The relevance of salience is demonstrated by exploring the question of why the norm against incendiary weapons was adopted in the Convention on Certain Conventional Weapons (CCW) in 1980, and why the norm against cluster munitions was not, even though both weapons were deemed particularly inhumane and thus, put on the agenda when the CCW negotiations started in 1978. Drawing on secondary sources and on original data from public and institutional discourses, I study the influence of salience on the emergence of the anti-napalm norm and the non-emergence of the anti-cluster munitions norm in the period of 1945-80. The results demonstrate that and how the discrepancy in salience of the napalm and the cluster munitions issues mattered for the outcomes of the two norm-setting processes.
\end{abstract}

Keywords: International Norms; Norm Emergence; Salience; Weapons Prohibitions; Cluster Munitions; Napalm

\section{Introduction}

What determines which problems are addressed through international norms? Is it their severity, their framing, their visibility? And how do these factors affect each other? Numerous studies on international norms suggest that active and committed norm entrepreneurs, who raise problem awareness, construct a resonant framing, mobilise their audience, pressure the norm addressees, and create conducive institutional conditions, matter most for norm emergence. ${ }^{1}$ But what about those cases where these conditions seem to be present, and yet, the norm-setting process fails? ${ }^{2}$

\footnotetext{
${ }^{1}$ Ethan Nadelmann, 'Global prohibition regimes: the evolution of norms in international society', International Organization, 44:4 (1990), pp. 479-526; Martha Finnemore and Kathryn Sikkink, 'International norm dynamics and political change', International Organization, 52:4 (1998), pp. 887-917; Margaret E. Keck and Kathryn Sikkink, Activists beyond Borders: Advocacy Networks in International Politics (Ithaca: Cornell University Press, 1998); Rodger A. Payne, 'Persuasion, frames and norm construction', European Journal of International Relations, 7:1 (2001), pp. 37-61; Jutta Joachim, 'Framing issues and seizing opportunities: the UN, NGOs, and women's rights', International Studies Quarterly, 47:2 (2003), pp. 247-74; Nicole Deitelhoff, 'The discursive process of legalization: Charting islands of persuasion in the ICC case', International Organization, 63:1 (2009), pp. 33-65; Dongwook Kim, 'International non-governmental organizations and the abolition of death penalty', European Journal of International Relations, 22:3 (2016), pp. 596-621.

${ }^{2}$ The non-emergence of norms has become a research focus only recently; see Thomas Richard Davies, The Possibilities of Transnational Activism: The Campaign for Disarmament Between the Two World Wars (Leiden and Boston: Martinus
}

This is an Open Access article, distributed under the terms of the Creative Commons Attribution licence (http://creativecommons.org/ licenses/by/4.0/), which permits unrestricted re-use, distribution, and reproduction in any medium, provided the original work is properly cited. (c) British International Studies Association 2018. 
This article highlights the decisive role of issue salience in explaining such outcomes by showing that high salience facilitates norm emergence, while low salience inhibits it.

Recently, several authors have urged to study salience systematically. ${ }^{3}$ But since salience is not a completely unknown concept to norm research, why is it worthwhile to take up the plea and what is the new argument about salience that this article makes? First, paying attention to attention sensitises us to the discrepancies between the severity and urgency of some problems and their visibility discrepancies that matter because one of their consequences is that certain problems are neglected by both norm entrepreneurs and by political decision-makers. Second, central norm-related concepts like agenda-setting and awareness-raising suggest that issue salience is a result of advocacy, ${ }^{4}$ but I argue that salience has a distinct explanatory value in that it affects advocacy decisions.

Third, the term salience is being used inconsistently in norm research, denoting rather different features of norms, which are, moreover, already covered by other concepts - like strength, ${ }^{5}$ resonance, ${ }^{6}$ internalisation and acceptance, ${ }^{7}$ influence, ${ }^{8}$ or prominence and commitment. ${ }^{9}$ In contrast, this article makes a case for a narrow definition of salience, which is common in communication and agenda-setting research, ${ }^{10}$ but rare in norm research: ${ }^{11}$ Salience is defined as the amount of attention granted to an issue and reflected in agendas - 'set[s] of issues that are viewed at a point in time as ranked in a hierarchy of importance'. ${ }^{12}$ In addition to providing a

Nijhoff Publishers, 2007); R. Charli Carpenter, 'Setting the advocacy agenda: Theorizing issue emergence and nonemergence in transnational advocacy networks', International Studies Quarterly, 51:1 (2007), pp. 99-120; R. Charli Carpenter, 'Studying issue (non)-adoption in transnational advocacy networks', International Organization, 61:3 (2007), pp. 643-67; Jennifer L. Bailey, 'Arrested development: the fight to end commercial whaling as a case of failed norm change', European Journal of International Relations, 14:2 (2008), pp. 289-318; R. Charli Carpenter, 'Vetting the advocacy agenda: Network centrality and the paradox of weapons norms', International Organization, 65:1 (2011), pp. 69-102; Suzette R. Grillot, 'Global gun control: Examining the consequences of competing international norms', Global Governance, 17:4 (2011), pp. 529-55; Lindsey N. Kingston, “'A forgotten human rights crisis": Statelessness and issue (non-)emergence', Human Rights Review, 14:2 (2013), pp. $73-87$.

${ }^{3}$ Carpenter, 'Vetting the advocacy agenda', p. 117; Phillip M. Ayoub, 'Contested norms in new-adopter states: International determinants of LGBT rights legislation', European Journal of International Relations, $21: 2$ (2015), p. 313; Catherine Hecht, 'The shifting salience of democratic governance: Evidence from the United Nations General Assembly General Debates', Review of International Studies, 42:5 (2016), pp. 915-38.

${ }^{4}$ Keck and Sikkink, Activists beyond Borders, p. 20; Ann Marie Clark, Diplomacy of Conscience: Amnesty International and Changing Human Rights Norms (Princeton: Princeton University Press, 2001), p. 34; Carpenter, 'Vetting the advocacy agenda'; Justin Gest et al., 'Tracking the process of international norm emergence: a comparative analysis of six agendas and emerging migrants' rights', Global Governance, 19:2 (2013), p. 164.

${ }^{5}$ Andrew P. Cortell and James W. Davis Jr, 'Understanding the domestic impact of international norms: a research agenda', International Studies Review, 2:1 (2000), pp. 68-9.

${ }^{6}$ Frank Schimmelfennig, 'Introduction: the impact of international organization on the central and Eastern European states - conceptual and theoretical issues', in Ronald H. Linden (ed.), Norms and Nannies: The Impact of International Organizations on the Central and East European States (Lanham: Rowman \& Littlefield, 2002), p. 14.

${ }^{7}$ Andrew P. Cortell and James W. Davis Jr, 'When norms clash: International norms, domestic practices, and Japan's internalisation of the GATT/WTO', Review of International Studies, 31:1 (2005), p. 8.

${ }^{8}$ Loren R. Cass, The Failures of American and European Climate Policy: International Norms, Domestic Politics, and Unachievable Commitments (Albany: State University of New York Press, 2006), p. 3.

${ }^{9}$ Karisa Cloward, When Norms Collide: Local Responses to Activism Against Female Genital Mutilation and Early Marriage (New York: Oxford University Press, 2016), p. 19.

${ }^{10}$ Jian-Hua Zhu, 'Issue competition and attention distraction: a zero-sum theory of agenda-setting', Journalism Quarterly, 69:4 (1992), pp. 825-36; James W. Dearing and Everett M. Rogers, Agenda-Setting (Thousand Oaks, CA: Sage, 1996), p. 8; Jens Newig, 'Public attention, political action: the example of environmental regulation', Rationality and Society, 16:2 (2004), pp. 153-5; Dietram A. Scheufele and David Tewksbury, 'Framing, agenda setting, and priming: the evolution of three media effects models', Journal of Communication, 57:1 (2007), p. 11; Kenneth T. Andrews and Neal Caren, 'Making the news: Movement organizations, media attention, and the public agenda', American Sociological Review, 75:6 (2010), p. 847.

${ }^{11}$ For exceptions, see Gregory A. Raymond, 'Neutrality norms and the balance of power', Cooperation and Conflict, 32:2 (1997), pp. 123-46; or Carpenter, 'Vetting the advocacy agenda'.

${ }^{12}$ Everett M. Rogers, James W. Dearing, and Soonbum Chang, 'AIDS in the 1980s: the agenda-setting process for a public issue', Journalism Monographs, 126 (1991), p. 6. 
well-defined focus of study, this attention-based understanding opens space for a differentiated analysis and allows comparisons, for example, of the salience of the same norm to different audiences or over time, as well as of the salience of different norms.

The present study demonstrates the theoretical and empirical value of salience with regard to norm emergence, but salience is also worth further exploration with regard to other aspects of norm evolution, namely norm diffusion and norm erosion. The international diffusion of norms is usually captured through the adoption of respective legislative acts and/or through normcompliant behaviour. ${ }^{13}$ Studying the salience of these norms might complement the picture (or produce a different one) by revealing how they took hold, and it might explain the patterns observed in law and compliance. Also, while I will show a positive relationship between salience and norm emergence, the effects of salience on norm diffusion appear to be ambivalent. ${ }^{14}$ Regarding norm erosion, if we extrapolate from Martha Finnemore's and Kathryn Sikkink's argument that internalised norms 'acquire a taken-for-granted quality and are no longer a matter of broad public debate, ${ }^{15}$ increases in salience might help detect eroding international norms and reveal when the erosion began. ${ }^{16}$

The main argument of this article is that salience, generated through journalistic selection, issue attributes, and attention dynamics, affects norm emergence through its impact on four other factors, namely on norm entrepreneurs, mobilisation, social pressure, and framing. Salient issues will be more likely adopted by gatekeepers and promoted by norm entrepreneurs. Furthermore, salient issues will more likely inspire mobilisation and social pressure. For framing, salience functions as a precondition of becoming noticeable - the most resonant framing will not be effective if its addressees are not aware of it.

To probe the hypothesised relationship between salience and norm emergence, I focus on the issue area of inhumane weapons, and in particular, on the adoption of the norm against incendiary weapons and the non-adoption of the norm against cluster munitions in the Convention on Certain Conventional Weapons (CCW). ${ }^{17}$ This focus is suitable for my purposes for three reasons. First, the fact that the adoption of CCW in 1980 exhibits simultaneous instances of both emergence and non-emergence of norms allows for controlling for alternative explanations, and thus, for assessing the relevance of salience. Second, I posit that salience particularly matters in contentious processes - and norms regulating the use of certain weapons are usually met with

\footnotetext{
${ }^{13} \mathrm{Judith}$ Kelley, 'Assessing the complex evolution of norms: the rise of international election monitoring', International Organization, 62:2 (2008), pp. 221-55; Susan Hyde, 'Catch us if you can: Election monitoring and international norm diffusion', American Journal of Political Science, 55:2 (2011), pp. 356-69.

${ }^{14}$ As Karisa Cloward posits, salient norms not only mobilise local activism, but also might increase the resistance towards them or distort the motives of norm entrepreneurs for norm adoption; see Cloward, When Norms Collide, pp. 19-20.

${ }^{15}$ Finnemore and Sikkink, 'International norm dynamics', p. 895.

${ }^{16}$ On norm erosion, see Elvira Rosert and Sonja Schirmbeck, 'Zur Erosion internationaler Normen: Folterverbot und nukleares Tabu in der Diskussion', Zeitschrift für Internationale Beziehungen, 14:2 (2007), pp. 253-87; Ryder McKeown, 'Norm regress: US revisionism and the slow death of the torture norm', International Relations, 23:5 (2009), pp. 5-25; Diana Panke and Ulrich Petersohn, 'Why international norms disappear sometimes', European Journal of International Relations, 18:4 (2011), pp. 719-42; Regina Heller, Martin Kahl, and Daniela Pisoiu, 'The "dark" side of normative srgumentation - the case of counterterrorism policy', Global Constitutionalism, 1:2 (2012), pp. 278-312; Mathias Großklaus, 'Friction, not erosion: Assassination norms at the fault line between sovereignty and liberal values', Contemporary Security Policy, 38:2 (2017), pp. 260-80.

${ }^{17}$ Full title of the Convention: Convention on Prohibitions or Restrictions on the Use of Certain Conventional Weapons Which May Be Deemed to Be Excessively Injurious or to Have Indiscriminate Effects. For background information on the convention, see Richard R. Baxter, 'Conventional weapons under legal prohibitions', International Security, 1:3 (1977), pp. 42-61; Malcolm Shaw, 'The United Nations Convention on Prohibitions or Restrictions on the Use of Certain Conventional Weapons', Review of International Studies, 9:2 (1983), pp. 109-21; Roman Hunger, 'The Convention on Certain Conventional Weapons', Strategic Insights, 2:3 (2003), pp. 1-6; Robert J. Mathews, 'The 1980 Convention on Certain Conventional Weapons: a useful framework despite earlier disappointments', International Review of the Red Cross, 83:844 (2001), pp. 9911012; Stephanie Carvin, 'Conventional thinking? The 1980 Convention on Certain Conventional Weapons and the politics of legal restraints on weapons during the Cold War', Journal of Cold War Studies, 19:1 (2017), pp. 38-69.
} 
resolute resistance because they belong to the essential domain of security policy. Third, and additionally to its theoretical aspirations, this article contributes empirically to research on weapons prohibitions by analysing original data on two cases that have not received much attention thus far: Neither is there a study tracing the emergence of the norm on incendiary weapons, ${ }^{18}$ nor is there one attempting to explain the failure to prohibit cluster munitions in the 1970s. ${ }^{19}$

Understanding why norms against some weapons emerge but not against others is inherently relevant because these norms save lives. But even in the large body of insightful research on nonuse norms on certain weapons, this puzzle has not been sufficiently addressed. Most of the (single case) studies were pursuing other research aims: to demonstrate that and how weapons norms matter in shaping state behaviour, ${ }^{20}$ to trace the evolution of the taboos on particular weapons, ${ }^{21}$ and to examine the role of specific institutions in weapons development. ${ }^{22}$ Stressing the importance of the social construction of inhumanity, this research has identified central discursive stigmatisation figures such as the weapons' destructiveness, their secrecy, their long-term impact or their association with weakness and uncivilised warfare. Only recently and sporadically, a comparative perspective is emerging, which draws attention to the contingency of these discourses and highlights resulting inconsistencies of the practices of weapons regulation namely, banning certain weapons while ignoring other weapons whose effects might be considered equivalent. ${ }^{23}$ It is this line of argument that I build upon and advance by arguing that we need to consider salience to understand why particular weapons are singled out for prohibition by the gatekeepers, and why some norm-setting efforts succeed while others fail.

Guided by the question of why the norm against incendiary weapons was adopted in the CCW and why the norm against cluster munitions was not, this article is organised as follows. In the

\footnotetext{
${ }^{18}$ Richard M. Neer's illuminating historical monograph on napalm is the only exception; see Robert M. Neer, Napalm: An American Biography (Cambridge, MA: Belknap Press of Harvard University Press, 2013).

${ }^{19}$ The recent success of the norm on cluster munitions has been explained quite often; see Margarita H. Petrova, 'Curbing the use of indiscriminate weapons: NGO advocacy in militant democracies', in Matthew Evangelista, Harald Müller, and Niklas Schörnig (eds), Democracy and Security. Preferences, Norms and Policy-Making (London and New York: Routledge, 2008), pp. 72-101; John Borrie, Unacceptable Harm: A History of How the Treaty Banning Cluster Munitions Was Won (Geneva and New York: UNIDIR, 2009); Matthew Bolton and Thomas Nash, 'The role of middle power-NGO coalitions in global policy: the case of the cluster munitions ban', Global Policy, 1:2 (2010), pp. 172-84; Margarita H. Petrova, 'Rhetorical entrapment and normative enticement: How the United Kingdom turned from spoiler into champion of the cluster munition ban', International Studies Quarterly, 16:3 (2016), pp. 387-99; Margarita H. Petrova, 'Weapons prohibitions through immanent critique: NGOs as emancipatory and (de)securitising actors in security governance', Review of International Studies, First View (2018), pp. 1-35.

${ }^{20}$ Nina Tannenwald, 'The nuclear taboo: the United States and the normative basis of nuclear non-use', International Organization, 53:3 (1999), pp. 433-68; Theo Farrell and Hélène Lambert, 'Courting controversy: International law, national norms and American nuclear use', Review of International Studies, 27:3 (2001), pp. 309-26; Thomas M. Dolan, 'Unthinkable and tragic: the psychology of weapons taboos in war', International Organization, 67:1 (2013), pp. 37-63; Adam Bower, 'Norms without the Great Powers: International law, nested social structures, and the ban on antipersonnel mines', International Studies Review, 17:3 (2015), pp. 347-73; Susan B. Martin, 'Norms, military utility, and the use/non-use of weapons: the case of anti-plant and irritant agents in the Vietnam War', Journal of Strategic Studies, 39:3 (2016), pp. 321-64; Frank Sauer, Atomic Anxiety: Deterrence, Taboo and the Non-Use of U.S. Nuclear Weapons (London: Palgrave Macmillan, 2016).

${ }^{21}$ Richard Price, 'A genealogy of the chemical weapons taboo', International Organization, 49:1 (1995), pp. 73-103; Richard Price, The Chemical Weapons Taboo (Ithaca: Cornell University Press, 1997); Richard Price, 'Reversing the gun sights: Transnational civil society targets land mines', International Organization, 52:3 (1998), pp. 613-44; Nina Tannenwald, 'Stigmatizing the bomb: Origins of the nuclear taboo', International Security, 29:4 (2005), pp. 5-49; Catherine Jefferson, 'Origins of the norm against chemical weapons', International Affairs, 90:3 (2014), pp. 647-61; Patricia Shamai, 'Name and shame: Unravelling the stigmatization of weapons of mass destruction', Contemporary Security Policy, 36:1 (2015), pp. 10422; Ingvild Bode and Hendrik Huelss, 'Autonomous weapons systems and changing norms in International Relations', Review of International Studies, First View (2018), pp. 1-21.

${ }^{22}$ M. Patrick Cottrell, 'Legitimacy and institutional replacement: The Convention on Certain Conventional Weapons and the Emergence of the Mine Ban Treaty', International Organization, 63:2 (2009), pp. 217-48.

${ }^{23}$ Carpenter, 'Vetting the advocacy agenda'; Neil Cooper, 'Humanitarian arms control and processes of securitization: Moving weapons along the security continuum', Contemporary Security Policy, 32:1 (2011), pp. 134-58.
} 
first section, I introduce the theoretical argument by conceptualising salience and its impact on other explanatory factors. Subsequently, I develop the puzzle by providing details on both weapons and outlining their common characteristics. I then present the empirical results of my study, which show a striking discrepancy in the salience of the two issues. Synthetising the results, the next section explains why and how salience affected the outcomes of the two normsetting processes. In the conclusion, I discuss the generalisability of the results.

\section{Salience and norm emergence}

Building on the insight that the media agenda is crucial for the fate of public issues, ${ }^{24}$ one of the essential claims of norm research is that norm entrepreneurs initiate salience-generating media campaigns. While not disputing this assumption, in this section I introduce three factors other than norm entrepreneurship that facilitate issue salience; journalistic selection decisions, issue attributes, and attention dynamics. In the second step, I sketch out how salience may serve as a precondition both to norm adoption through norm entrepreneurs and to the very processes that norm entrepreneurs push forward.

Norm research acknowledges the media as essential allies of norm entrepreneurs, disseminating the latter's messages to the public. ${ }^{25}$ However, the media do not only have the power to determine which issues are important enough to receive attention and to choose from a repertoire of topics, but also the power to initiate and promote their own issues and interests. ${ }^{26}$ Since such initial media reporting is often necessary for norm entrepreneurs to learn about certain problems and to set them on their agenda, ${ }^{27}$ journalistic selection decisions are a precondition to salience. The main factor affecting those decisions is the 'news value' of an issue, which is less determined by the inherent presence or strength of the attributes, but rather by how journalists perceive and construct them. ${ }^{28}$ Among the main attributes increasing this value are so-called triggering events (characterised by unexpectedness, rarity, intensity, and/or spatial extent), ideally followed by related events, which produce a regular stream of new information. ${ }^{29}$ Other attributes are personification, proximity, risks, controversy, and conflicts. ${ }^{30}$

After the issues pass the initial selection filter, changes in salience over time, that is, rises and declines of attention, are driven by three main mechanisms of issue-attention cycles: attention thresholds and cascades, saturation effects, and issue displacement. ${ }^{31}$ To take off, issues need to

\footnotetext{
${ }^{24}$ Maxwell McCombs and Donald L. Shaw, 'The agenda-setting function of mass media', The Public Opinion Quarterly, $36: 2$ (1972), pp. 176-87.

${ }^{25}$ Keck and Sikkink, Activists beyond Borders, p. 23; Matthew Krain, 'J'accuse! Does naming and shaming perpetrators reduce the severity of genocides or politicides?', International Studies Quarterly, 56:3 (2012), p. 575; Gest et al., 'Tracking the process of international norm emergence', pp. 162-3.

${ }^{26}$ Shanto Iyengar and Donald R. Kinder, News That Matters: Television and American Opinion (Chicago: University of Chicago Press, 1987), p. 33; Ruud Koopmans, 'Movements and media: Selection processes and evolutionary dynamics in the public sphere', Theory and Society: Renewal and Critique in Social Theory, 33:3 (2004), p. 373; Andrews and Caren, 'Making the news', p. 843.

${ }^{27}$ Carpenter, 'Studying issue (non)-adoption', p. 646.

${ }^{28}$ Christiane Eilders, 'News factors and news decisions: Theoretical and methodological advances in Germany', Communications: The European Journal of Communication Research, 31:1 (2006), pp. 11-12; Annie Waldherr, 'Emergence of news waves: a social simulation approach', Journal of Communication, 64:5 (2014), p. 856.

${ }^{29}$ Dearing and Rogers, Agenda-Setting, p. 78; Jenny Kitzinger and Jacquie Reilly, 'The rise and fall of risk reporting: Media coverage of human genetics research, "false memory syndrome" and "mad cow disease", European Journal of Communication, 12:3 (1997), p. 335.

${ }^{30}$ Eilders, 'News factors', p. 8; Rogers, Dearing, and Chang, 'AIDS in the 1980s', p. 41; Monika Djerf-Pierre, 'The crowdingout effect', Journalism Studies, 13:4 (2012), p. 503.

${ }^{31}$ Anthony Downs, 'Up and down with ecology - the "issue-attention cycle”, Public Interest, 28 (1972), pp. 38-50; Eilders, 'News factors'; James K. Hertog, John. R Finnegan Jr, and Emily Kahn, 'Media coverage of AIDS, cancer, and sexually transmitted diseases: a test of the public arenas model', Journalism Quarterly, 71:2 (1994), pp. 291-304; Stephen Hilgartner and Charles L. Bosk, 'The rise and fall of social problems: a public arena model', American Journal of Sociology, 94:1 (1988),
} 


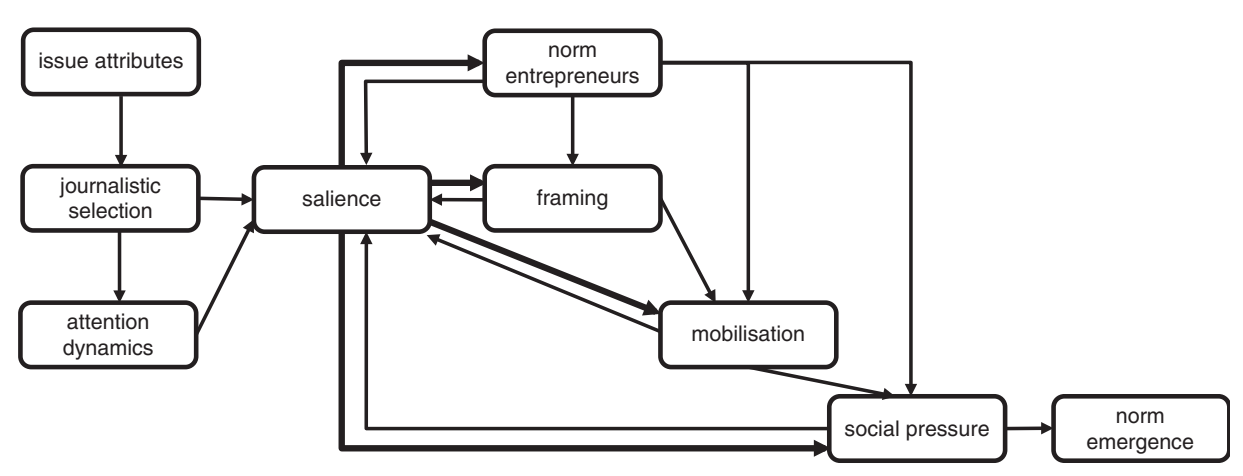

Figure 1. The effects of salience on norm emergence.

overcome the attention threshold, but once reached, a certain salience alone makes issues more attractive and stimulates a cascade - a rapid increase in attention. Cascades matter for other, related issues at the same time as they produce spill-over effects, and they matter for the same issue in the longer run, as it is easier to reactivate issues if they had reached a certain salience in the past because they appear familiar. Declines in salience are partly caused by saturation effects (or issue fatigue), which denote the exhaustion of interest for issues that have been salient for some time. This process is accelerated through the emergence of new issues - they have the capacity to displace old issues because their news value is higher and because they are in the more dynamic stage of the cycle.

The model presented in Figure 1 hinges between previous and following sections by depicting the factors generating pre-advocacy salience and the factors usually deemed to be necessary for norm emergence, such as issue adoption by norm entrepreneurs, mobilisation, social pressure, and framing. Because we are dealing with mutual influence and multidirectional causality here, the model implies the causal path from norm entrepreneurship to salience, which has been established in the research on international norms already. Its focus, however, is on the reverse casual path - the one leading from salience to norm entrepreneurship and resulting factors.

The model concurs with norm research in assuming norm entrepreneurs to be the condition sine qua non for norm emergence. ${ }^{32}$ It also echoes the research on the role of gatekeepers and on issue selection, which stresses organisational interests and strategic considerations in issue adoption decisions. ${ }^{33}$ In determining which issues deserve transnational commitment, norm entrepreneurs assess whether an issue is easy to brand and to transmit, likely to acquire funding and to meet the interests of other institutional partners. ${ }^{34}$ But issue salience, I argue, is an additional factor figuring into those calculations. Salient issues will be more likely adopted by gatekeepers and promoted by norm entrepreneurs for two reasons: These actors are more likely

pp. 53-78; Kitzinger and Reilly, 'The rise and fall of risk reporting'; Koopmans, 'Movements and media'; W. Russell Neumann, 'The threshold of public attention', Public Opinion Quarterly, 54:2 (1990), pp. 159-76; Newig, 'Public attention'; Waldherr, 'Emergence of news waves'; Zhu, 'Issue competition'.

${ }^{32}$ Robert W. McElroy, Morality and American Foreign Policy: The Role of Ethics in International Affairs (Princeton: Princeton University Press, 1992), p. 180; Keck and Sikkink, Activists beyond Borders, p. 2.

${ }^{33}$ Clifford Bob, 'Merchants of morality', Foreign Policy, 129 (2002), p. 38; R. Charli Carpenter, Forgetting Children Born of War: Setting the Human Rights Agenda in Bosnia and Beyond (New York: Columbia University Press, 2010), p. 46; Carpenter, 'Vetting the advocacy agenda', p. 88.

${ }^{34}$ Clifford Bob, 'Marketing rebellion: Insurgent groups, international media, and NGO support', International Politics, 38:3 (2001), p. 327; Alexander Cooley and James Ron, 'The NGO scramble - organizational insecurity and the political economy of transnational action', International Security, 27:1 (2002), pp. 6-9; Judith Kelley, 'D-minus elections: the politics and norms of international election observation', International Organization, 63:4 (2009), p. 782; Carpenter, Forgetting Children Born of War, p. 46; Carpenter, 'Vetting the advocacy agenda', p. 88; George E. Mitchell and Hans Peter Schmitz, 'Principled instrumentalism: a theory of transnational NGO behaviour', Review of International Studies, 40:3 (2014), pp. 487-504. 
to become aware of salient problems, and they are more likely to invest their resources in salient issues because they deem the latter's chances to be regulated as higher.

Another common assumption the model shares is that in contentious norm-setting processes, a high level of social pressure is necessary for norm emergence. Once the issue has been adopted, norm entrepreneurs increase social pressure on the norm addressees in two ways: indirectly, through addressing the 'targets of mobilization', and directly, through addressing the 'targets of influence, ${ }^{35}$ The targets of mobilisation are actors with leverage (often the public, advocacy networks or other states) who are supposed to become active and to exert influence over the norm addressees. To mobilise them, norm entrepreneurs launch so-called awareness raising campaigns, which aim at increasing issue salience through information politics, consisting of instruments like reports, posters, or websites, and through action politics, consisting of instruments like demonstrations or fundraisers. ${ }^{36}$ At the same time, due to cascade effects described above, mobilisation is more likely for issues that are salient already or have been salient in the past.

The targets of influence are the addressees of a norm themselves (mostly states, but also enterprises, or other non-state actors), that is, those actors who are supposed to adjust their attitude, or at least their behaviour, to the norm. Social pressure is supposed to affect their costbenefit calculations by distributing social punishments and rewards. ${ }^{37}$ To exert social pressure, norm entrepreneurs blame and shame the norm addressees by exposing norm-violating behaviour and norm-rejecting attitudes as well as casting their targets in a negative way. ${ }^{38}$ In addition, praising (or altercasting), which is the other side of the coin, occurs. It refers to social rewards granted for norm support and the attribution of positive roles. ${ }^{39}$ Same as mobilisation, social pressure does not only increase issue salience, but is also easier to exercise if it is related to issues that are salient already.

Framing is another established strategic element of norm-setting efforts that the model incorporates. Norm entrepreneurs use framing to define collective understandings of issues by ascribing meanings, defining categories, spinning narratives, grafting normative resources onto each other, embedding issues into normative networks, and using techniques like attribution, repetition, and association to promote certain perspectives on issues while excluding others. ${ }^{40}$ While I agree that specific framing characteristics (for example, concreteness or simplicity) certainly explain why some issues become salient and others do not, my argument regarding salience and framing is twofold. First, I follow Maxwell McCombs and Salma L. Ghanem by arguing that salience is not only a distinct feature of issues, but also a feature of framing strategic framing is all about making some attributes (and narratives and frames) more salient than other, competing attributes. ${ }^{41}$ Second, I argue that issue salience is a precondition to the visibility of framing, since a framing that exhibits all favourable characteristics can still be invisible to the public.

In sum, in contrast to the literature that highlights the potential of norm entrepreneurs to increase issue salience through a favourable framing, mobilisation, and social pressure, I argue that issue salience itself affects those factors: Salience increases the chances of an issue to be adopted by norm entrepreneurs; it makes mobilisation and social pressure easier, and it allows

\footnotetext{
${ }^{35}$ William A. Gamson, The Strategy of Social Protest (Belmont, CA: Wadsworth Publishing Company, 1990), pp. 14-15.

${ }^{36}$ Keck and Sikkink, Activists beyond Borders, pp. 19-25; Clark, Diplomacy of Conscience, p. 34.

${ }^{37}$ Alastair Iain Johnston, 'Treating international institutions as social environments', International Studies Quarterly, 45:4 (2001), p. 499.

${ }^{38}$ Frank Schimmelfennig, 'The community trap: Liberal norms, rhetorical action, and the eastern enlargement of the European Union', International Organization, 55:1 (2001), pp. 64-5.

${ }^{39}$ Petrova, 'Rhetorical entrapment', p. 390.

${ }^{40}$ Keck and Sikkink, Activists beyond Borders, pp. 10-19; Price, 'Reversing the gun sights', pp. 628-30; Payne, 'Persuasion'.

${ }^{41}$ Maxwell McCombs and Salma L. Ghanem, 'The convergence of agenda setting and framing', in Stephen D. Reese Jr, Oscar H. Gandy, and August E. Grant (eds), Framing Public Life: Perspectives on Media and Our Understanding of the Social World (Mahwah, NJ: Lawrence Erlbaum Associates, 2001), pp. 67-9; Joachim, 'Framing issues', p. 251.
} 
the issue's framing to become visible. Hence, I do not claim that salience is a rival explanation to the established ones. Rather, my interest is to study salience in conjunction with them and to demonstrate that it is a necessary element of the explanation, the consideration of which produces a more complete account of the emergence and non-emergence of norms.

\section{Incendiary weapons and cluster munitions in the CCW: Background and alternative explanations}

When the CCW negotiations began in 1978, several weapons, namely anti-personnel fragmentation weapons (known today as cluster munitions or cluster bombs), flechettes, fuel-air explosives, incendiary weapons, landmines, non-detectable fragments, and small-calibre weapons were proposed for restrictions because they were deemed particularly inhumane and contrary to the provisions of International Humanitarian Law (IHL). ${ }^{42}$ The final document, however, only included protocols on three weapon categories: Protocol I prohibited the use of weapons producing non-detectable fragments; Protocols II and III restricted (but did not prohibit) the use of certain weapons - the former of mines and booby traps, the latter of incendiary weapons such as napalm. Following the logic of a most similar systems design, the different outcomes in the cases of incendiary weapons and cluster munitions seem to be the most puzzling, as both weapon types share some common characteristics regarding potential explanatory factors, namely inhumanity, military utility, and institutional setting.

Both incendiary weapons and cluster munitions qualify as inhumane due to their indiscriminateness and according to the criteria proposed by the International Committee of the Red Cross (ICRC). ${ }^{43}$ Incendiary weapons burn people, often to death; cluster munitions tear them apart. Napalm-inflicted burns affect large areas of the human body and are especially severe, destroying the outer and the inner layer of skin as well as the tissue, nerve endings, and muscles, leading to third- or even fourth-degree burns. ${ }^{44}$ Cluster munitions inflict large and deep wounds and penetrate the human body with tiny pieces of shrapnel; incidents with unexploded submunitions, which still occur long after the end of conflicts, lead to losses of limbs, blindness, and disfigurement. ${ }^{45}$ The use of both weapons results in high mortality rates and extremely painful, severe, and large-area injuries, and both cause permanent disfigurement and disabilities to their survivors who might need complicated and long, often permanent, medical treatment.

Two observations invalidate the explanation that states merely agree to regulate weapons that they consider obsolete anyway. ${ }^{46}$ First, massive uses of napalm and of cluster munitions in the Vietnam War indicate that both weapons were considered militarily effective. ${ }^{47}$ Second, ban

\footnotetext{
${ }^{42}$ A/CONF.95/3, Report of the Preparatory Conference for the United Nations Conference on Prohibitions or Restrictions of Use of Certain Conventional Weapons Which May Be Deemed to be Excessively Injurious or To Have Indiscriminate Effects, 25 May 1979, pp. 2-3.

${ }^{43}$ See Robin M. Coupland, The SIrUS Project: Towards a Determination of Which Weapons Cause 'Superfluous Injury or Unnecessary Suffering' (Geneva: International Committee of the Red Cross, 1997), pp. 22-6.

${ }^{44}$ Denise Chong, The Girl in the Picture: The Remarkable Story of Vietnam's Most Famous Casualty (London: Simon \& Schuster UK Ltd, 1999), p. 89; Kim Coleman, A History of Chemical Warfare (Houndmills, Basingstoke: Palgrave Macmillan, 2005), p. 95.

${ }^{45}$ Eric Prokosch, The Technology of Killing: A Military and Political History of Antipersonnel Weapons (London and New Jersey: Zed Books, 1995), pp. 88-9; Thomas Michael McDonnell, 'Cluster bombs over Kosovo: a violation of international law?', Arizona Law Review, 44:1 (2002), p. 70; Petrova, 'Rhetorical entrapment', p. 391.

${ }^{46}$ Andrew Latham, 'Theorizing the landmine campaign: Ethics, global cultural scripts, and the laws of war', in Rosalind Irwin (ed.), Ethics and Security in Canadian Foreign Policy (Vancouver: University of British Columbia Press, 2001), pp. 16078; Ritu Mathur, “'The West and the rest”: a civilizational mantra in arms control and disarmament?', Contemporary Security Policy, 35:3 (2014), pp. 332-55.

${ }^{47}$ Both weapons were developed and used first during the Second World War and in several conflicts thereafter. Napalm was used in the Korean War, in the Portuguese Colonial Wars, in the Ethiopian-Eritrean Wars and, more recently, in the Gulf War and in the Yugoslav Wars, inter alia. Cluster munitions were used in the Israel-Lebanon Wars, the Soviet-Afghan War, and in more recent conflicts, such as the Kosovo War or in the Iraq War, inter alia. On the social construction - and the
} 
opponents stressed the military necessity of incendiaries and presented studies demonstrating their efficiency and superiority to other weapons at CCW negotiations. ${ }^{48}$ And yet, a protocol restricting them was adopted eventually.

Another explanation that I exclude is the institutional setting. The latter is considered to provide (or lack) favourable conditions for persuasion, ${ }^{49}$ and to determine the possibilities of norm entrepreneurs to influence outcomes via access, participation, and decision-making rights. ${ }^{50}$ These factors, certainly playing a role in other cases, cannot explain the outcomes of interest here, since the norms on napalm and on cluster munitions were negotiated in the same institutional fora, and belonged to the same general norm-setting process that began after the Second World War and focused on a range of potentially inhumane methods and means of warfare. $^{51}$

Nevertheless, cluster munitions escaped a ban in the 1970 s, whereas a norm on napalm emerged. Protocol III of the CCW prohibits the use of incendiary weapons against civilians and civilian objects, but also against military objectives located within concentrations of civilians and against forests and other kinds of plant cover except when these are used to conceal military objectives. The norm has been criticised as weak in legal terms, ${ }^{52}$ but the social norm against incendiary weapons, and napalm in particular, is strong, despite occasional breaches. ${ }^{53}$ Right after the adoption of the CCW, incendiary weapons were deemed to be those conventional weapons that invoked the greatest public revulsion and that were outlawed even without a legal ban. $^{54}$ Today, authors still diagnose a 'near universal antipathy to napalm' amounting to the extent of 'public hysteria'. 55

limits - of military utility, see Price, 'Reversing the gun sights', pp. 631-7; Petrova, 'Rhetorical entrapment'; Petrova, 'Weapons prohibitions'.

${ }^{48}$ Neer, Napalm, pp. 189-90.

${ }^{49}$ Thomas Risse, “Let's argue!": Communicative action in world politics', International Organization, 54:1 (2000), pp. 139; Nicole Deitelhoff and Harald Müller, 'Theoretical paradise - empirically lost? Arguing with Habermas', Review of International Studies, 31:1 (2005), pp. 167-80; Deitelhoff, 'Discursive process'.

${ }^{50}$ Katharina P. Coleman, 'Locating norm diplomacy: Venue change in international norm negotiations', European Journal of International Relations, 19:1 (2013), pp. 167-8.

${ }^{51}$ See Hans Blix, 'Current efforts to prohibit the use of certain conventional weapons', Instant Research on Peace and Violence, 4:1 (1974), pp. 21-30; Frits Kalshoven, 'The Conference of Government Experts on the Use of Certain Conventional Weapons, Lucerne, 24 September-18 October 1974', Netherlands Yearbook of International Law, 6 (1975), p. 80; Paul Szasz, 'The Conference on Exclusively Injurious or Indiscriminate Weapons', American Journal of International Law, 74:1 (1980), pp. 212-15; Yves Sandoz, 'A new step forward in international law: Prohibitions or restrictions on the use of certain conventional weapons', International Review of the Red Cross, 220 (1981), pp. 3-18; Howard S. Levie, 'Prohibitions and restrictions on the use of conventional weapons', St. John's Law Review, 68:3 (1994), pp. 643-66.

${ }^{52}$ Ove Bring, 'Regulating conventional weapons in the future - humanitarian law or arms control?', Journal of Peace Research, 24:3 (1987), p. 277; Fritz Kalshoven, Constraints on the Waging of War (Dordrecht: Martinus Nijhoff Publishers, 1987), p. 187.

${ }^{53}$ According to Human Rights Watch, incendiary weapons (napalm and firebombs similar to it as well as white phosphorus) have been used in at least 16 conflicts since the adoption of the CCW (for example, by Argentina, Israel, Serbian nationalists, Turkey, the USSR and later Russia, the US, and most recently, by the Syrian government). But these instances of non-compliance provoked heavy criticism, and lately, calls by the humanitarian community to universalise Protocol III and to strengthen it substantially by closing its loopholes - reactions like these are commonly deemed to indicate the robustness rather than weakness of norms. See Human Rights Watch, Memorandum to Convention on Conventional Weapons Delegates The Human Suffering Caused by Incendiary Munitions (2011); Human Rights Watch, An Overdue Review: Addressing Incendiary Weapons in the Contemporary Context Memorandum to Delegates at the Meeting of States Parties to the Convention on Conventional Weapons (2017); Richard Price, 'Emerging customary norms and anti-personnel landmines', in Christian Reus-Smit (ed.), The Politics of International Law (Cambridge University Press, 2004), p. 114; Wayne Sandholtz, 'Dynamics of international norm change: Rules against wartime plunder', European Journal of International Relations, 14:2 (2008), p. 109.

${ }^{54}$ Sandoz, 'New step', p. 13; Levie, 'Prohibitions', pp. 662-3.

${ }^{55}$ Neer, Napalm, pp. 193-204. 
Meanwhile, a norm on cluster munitions has been adopted as well: In 2008, the so-called Oslo Process resulted in the Convention on Cluster Munitions, which not only fully prohibits their use, but also their stockpiling, production, and transfer. Finally, the inhumanity of these weapons has been recognised by international law. But what explains the initial failure of this norm - and the success of the anti-napalm norm?

\section{Method and data}

Following observations would support my argument. The basic expectation is that the outcomes of the norm-setting processes correspond to the salience of the issues: the emergence of the antinapalm norm should have been preceded by a high salience of the napalm issue; the nonemergence of the anti-cluster munitions norm should have been preceded by a low salience of the cluster munitions issue. Moreover, we should find that issue salience corresponds to other factors, that is, that high salience co-occurs with issue adoption by gatekeepers, high mobilisation, and high social pressure, whereas low issue salience does not. But since these relationships are multidirectional - how can we know what contributed to what? If consistent patterns of discrepancies are observed, the argument that salience affected the other factors and not vice versa implies a certain temporal succession, ${ }^{56}$ namely that discrepancies in salience occurred first, and discrepancies in other factors followed. To show that the visibility of framing matters, the framing substance of the two weapons should be similar, and the framing salience should be different.

The observations are drawn from both secondary sources and primary data, which shed light on the public and the institutional developments of the two norms of interest. The period covered by primary data (Table 1) begins on 1 January 1945, and accounts for the fact that both weapons were used on a large scale during the last months of the Second World War, and for the fact that the formalisation of international humanitarian law began after this war. ${ }^{57}$ It ends on 10 October 1980, the date of the adoption of the Convention on Certain Conventional Weapons.

Assuming the media discourse to reflect dominant political and societal discourses, I analysed the discourse in The New York Times and in The Guardian. ${ }^{58}$ The New York Times is often considered to be a newspaper of global scope, read by international decision-makers. ${ }^{59}$ The Guardian was included to correct the bias of the US-based New York Times during the Vietnam War, ${ }^{60}$ and because criticism of the use of napalm had been voiced in Great Britain already during the Korean War. ${ }^{61}$ Furthermore, The New York Times regularly included press clippings and letters to the editor from diverse regions of the world, which at least reduces the Northern bias problem (as does the institutional discourse in which speakers from all over the world were represented).

\footnotetext{
${ }^{56}$ Alexander Wendt, 'The international crisis - on constitution and causation in international relations', Review of International Studies, 24:5 (1998), p. 105; Henry E. Brady, 'Causation and explanation in social science', in Janet M. BoxSteffensmeier, Henry E. Brady, and David Collier (eds), The Oxford Handbook of Political Methodology (Oxford: Oxford University Press, 2008), pp. 231, 238.

${ }^{57}$ Janina Dill, Legitimate Targets? Social Construction, International Law and US Bombing (Cambridge: Cambridge University Press, 2015), pp. 4-5.

${ }^{58}$ To compile the media dataset, I used digital search engines and archives of both newspapers as well as the ProQuest database and included all articles in the research period that displayed the keywords 'napalm', 'cluster bomb', 'cluster munition', 'cluster weapon', or 'fragmentation bomb' in the sample.

${ }^{59}$ Matthew C. Nisbet and Mike Huge, 'Attention cycles and frames in the plant biotechnology debate: Managing power and participation through the press/policy connection', The Harvard International Journal of Press/Politics, 11:2 (2006), pp. 18-19; Uriel Abulof, 'We the peoples? The strange demise of self-determination', European Journal of International Relations, 22:3 (2015), p. 540.

${ }^{60}$ Todd Gitlin, The Whole World is Watching: Mass Media in the Making \& Unmaking of the New Left (Berkeley: University of California Press, 1980), pp. 271-3.

${ }^{61}$ Neer, Napalm, p. 113.
} 
Table 1. Final document sample. All documents were coded twice following the method of content analysis.

\begin{tabular}{lcc}
\hline & Documents & Coded segments \\
\hline Total & 3,138 & 4,594 \\
Media & 2,887 & 3,690 \\
-The New York Times & 2,060 & 2,595 \\
-The Guardian & 827 & 1,095 \\
Institutional & 251 & 903 \\
-UNGA & 128 & 302 \\
-ICRC & 67 & 393 \\
-UNCCW & 56 & 209 \\
\hline
\end{tabular}

To cover the institutional discourse, I focused on three institutions where the norm-setting processes on napalm and cluster munitions unfolded: the ICRC, the United Nations General Assembly (UNGA) and the United Nations Conference on Prohibitions or Restrictions on the Use of Certain Conventional Weapons Which May be Deemed to be Excessively Injurious or Have Indiscriminate Effects (UNCCW). ${ }^{62}$ The ICRC process included the conferences of government experts (CGE) in 1971 and in 1972 in preparation of the Diplomatic Conference on the Reaffirmation and Development of International Humanitarian Law Applicable in Armed Conflicts (CDDH) as well as the Ad Hoc Committee on Conventional Weapons of the CDDH, which met in several sessions between 1974 and 1977. The United Nations General Assembly and its relevant subcommittees regularly discussed the topic of inhumane weapons in the 1970s. The UNCCW met in one preparatory and two main sessions between 1978 and 1980 .

\section{Theory vis-à-vis the cases: Observations on salience and the norms against incendiary weapons and cluster munitions}

\section{Public salience, mobilisation, and social pressure}

In the public discourse, the salience of the napalm issue exceeded the salience of the cluster munitions issue by factor 7.3. Except for two years (1945 and 1978), napalm was consistently the more salient issue (Figure 2 and Table 2). The mobilisation, which I measured through the frequency of mobilising events, such as demonstrations, symbolic actions, press conferences and other public statements, mentioned in the media, was 14 times higher for napalm than for cluster munitions. Social pressure, which I measured through the frequency of statements blaming and shaming particular actors for issue-related actions, such as using, producing, or trading the weapons in question, was eight times higher for napalm. ${ }^{63}$

The napalm issue took off during the Korean War (1950-3), achieving the attention threshold due to a regular stream of information through daily United Nations communiqués and other articles on the daily progress of the war, which simply stated that napalm, among other weapons, was being used in combat (Figure 3). The issue had maintained a relatively high salience level for 12 months, before first acts of social pressure occurred, and for almost 2 years, before first acts of

\footnotetext{
${ }^{62}$ To compile the institutional dataset, I used digital research engines of the UN, the archives of UN depositary libraries, and the digital UN disarmament library, available at: \{https://disarmament-library.un.org\}. The complete ICRC-related documentation is available at: $\{\mathrm{http} / / / \mathrm{www}$. loc.gov/rr/frd/Military_Law/Geneva-Conventions_materials.html\}. Since I was interested in the process of institutional deliberations, I included only meeting records in the systematic analysis; other documents, like reports or resolutions, were sighted when necessary. I ran a digital search over all documents and included all meeting records displaying the keywords 'napalm', 'incendiary', 'cluster', or 'fragmentation' in the sample.

${ }^{63} \mathrm{On}$ anti-napalm protests, see Susan Schultz Huxman and Denice Beatty Bruce, 'Toward a dynamic generic framework of apologia: a case study of Dow chemical, Vietnam, and the napalm controversy', Communication Studies, 46:1-2 (1995), pp. 61-2; Prokosch, The Technology of Killing, pp. 126-31; Stanley Karnow, Vietnam: A History (New York: Penguin Books, 1997), pp. 502-04; Robert Hariman and John Louis Lucaites, 'Public identity and collective Memory in U.S. iconic photography: the image of "accidental napalm”', Critical Studies in Media Communication, 20:1 (2003), p. 40; Neer, Napalm, pp. 116-33; on cluster munitions, see Prokosch, The Technology of Killing, pp. 136-44.
} 

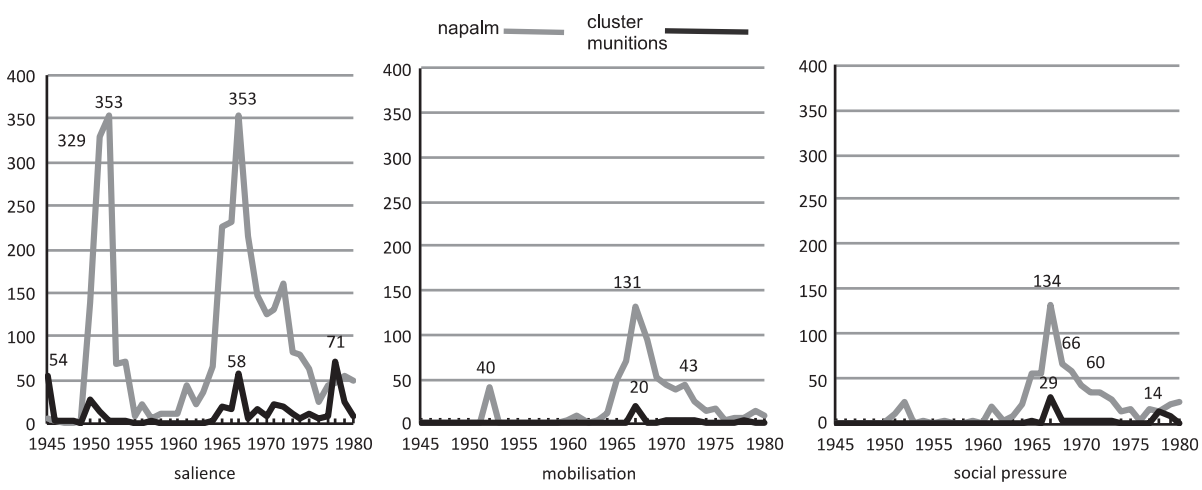

Figure 2. Public salience, mobilisation, and social pressure in coded segments per year (1945-80).

Table 2. Public salience, mobilisation, and social pressure. ()$=$ percent, distribution between the cases; ()$^{\star}=$ percent, distribution within the case.

\begin{tabular}{lccc}
\hline Codings & Cluster munitions & Napalm & Discrepancy \\
\hline Overall salience & $575(12)$ & $4,019(88)$ & 7.0 \\
Media salience & $445(12)$ & $3,245(88)$ & 7.3 \\
-The New York Times & $343(13)$ & $2,252(87)$ & 6.6 \\
-The Guardian & $102(9)$ & $993(91)$ & 9.7 \\
Mobilisation & 49 & 690 & 14.0 \\
Public social pressure & 89 & 734 & 8.2 \\
Targets of public social pressure & 9 & 36 & 30 \\
-states & 8 & 2 & 4 \\
-companies & 1 & US, 339 (43) \\
-others & 0 & Dow Chemical, 151 (19)* \\
-top targets & US, 56 (60) & Israel, $77(10)^{*}$ \\
\end{tabular}

mobilisation occurred. These acts - mainly letters to the editor, ${ }^{64}$ but also statements from churches $^{65}$ and resolutions by civil society organisations ${ }^{66}$ condemning napalm - were triggered by an article that interrupted the previous neutral reporting by describing in detail a person who had been struck by napalm. ${ }^{67}$ The report caused an outrage precisely because people had previously been reading daily about napalm without being alerted to its effects and were now shocked to learn what the weapons really did: 'Information from various sources concerning military operations in Korea creates the impression that the new weapon known as the napalm bomb is more horrible in its effects upon the human body than any previously used weapon of warfare except the atomic bomb. ${ }^{68}$ After this brief outburst, the issue's salience dropped to its previous level and then declined completely when the Korean War ended.

The decline was only temporary (Figure 4). At the beginning of the sixties, napalm re-entered the debate politicised: Portugal was criticised for having used napalm in Angola, and France was criticised for having used napalm in Tunisia. A steep increase in salience occurred when the US officially entered the Vietnam War in 1965. This war has fuelled the information stream related to napalm with two different components: war reporting and mobilising events. In total, both contributed to napalm's salience almost

\footnotetext{
${ }^{64}$ See, for example, 'The napalm bomb', The Guardian (13 March 1952).

${ }^{65} \mathrm{See}$, for example, the Archbishop of York, 'Napalm condemned', The Guardian (26 April 1952); the United Free Church of Scotland, 'Church condemns use of napalm bomb', The Guardian (5 June 1952).

${ }^{66}$ See, for example, the Women's Liberal Federation, 'Women liberals' concern', The Guardian (29 April 1952).

${ }^{67}$ Life in Korea', The Guardian (1 March 1952).

${ }^{68}$ 'Women liberals' concern', The Guardian.
} 

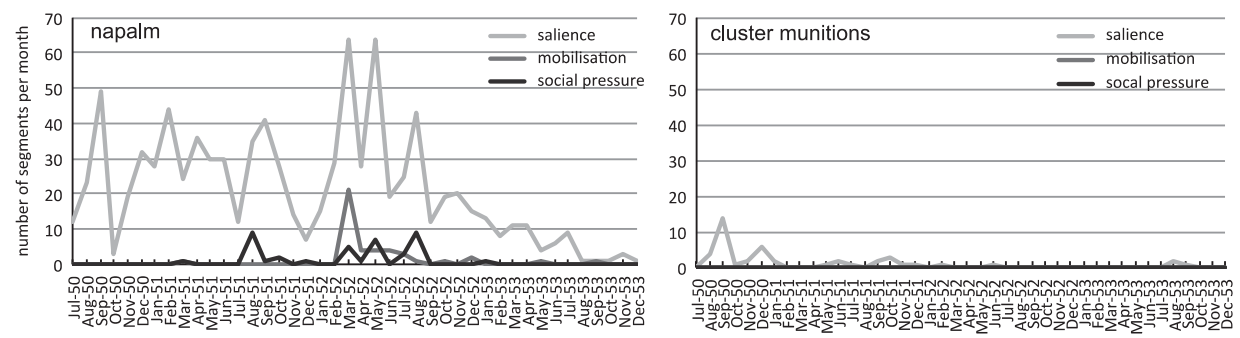

Figure 3. Public salience, mobilisation, and social pressure in coded segments per month (1950-3).

equally, but their proportions changed over time: In the first years of the war, reports about the use of napalm in the war prevailed, but from 1967 to 1970, reports related to mobilising events prevailed.

At its outset in the first half of the 1960s, mobilisation was largely marked by letters to the editors, voicing opposition to the Vietnam War and its atrocities, of which the use of napalm was one. The French philosopher Bertrand Russell was the first to openly criticise US policy, including the use of napalm, in a letter to The New York Times in $1963 .{ }^{69}$ The New York Times disputed Russell's accusations, ${ }^{70}$ but he insisted, ${ }^{71}$ supported by others. ${ }^{72}$ Less than one year later, it was again Russell, who criticised the use of napalm in a letter to The Guardian. ${ }^{73}$

In 1965, mobilisation against the Vietnam War in general, and the use of napalm in particular, started to intensify and to diversify, both in forms and in actors. Various anti-war groups were writing open letters to President Johnson ${ }^{74}$ and running anti-war advertisements; ${ }^{75}$ members of the UK parliament were addressing the president in telegrams; ${ }^{76}$ and Soviet representatives were criticising the war in speeches at the UN and elsewhere. ${ }^{77}$ The first anti-war demonstration referring to napalm was mentioned in April $1965,{ }^{78}$ and, with some delay, many other protests marches, sit-ins, and pickets followed. ${ }^{79}$ Various other mobilising actions, like the burning of draft files with napalm, on-site visits in Vietnam, or fundraisers for napalm victims, took place. ${ }^{80}$

After the wave of major protests receded, the issue remained salient because the stream of information was still present, but both salience and mobilisation declined until the end of the Vietnam War (with the exception of 1972 when the photo of the Trang Bang incident showing children fleeing from napalm was published). ${ }^{81}$ After this war, uses of napalm in other conflicts ${ }^{82}$ kept the issue on the agenda, but on a lower level.

${ }^{69}$ 'Vietnam policy protested', The New York Times (8 April 1963).

${ }^{70}$ 'Lord Russell's letter', The New York Times (8 April 1963).

${ }^{71}$ 'Bertrand Russell continues his attack on the United States', The New York Times (4 May 1963).

${ }^{72}$ 'Russell's view upheld', The New York Times (16 April 1963).

${ }^{73}$ 'Earl Russell and Vietnam', The Guardian (6 February 1964).

${ }^{74}$ See, for example: The New York Times (18 October 1964); (28 February 1965); (7 March 1965); (16 March 1965$)$; (26 March 1965); (13 February 1966). Also 'Churches debate Vietnam weapons', The Guardian (27 March 1965).

${ }^{75} \mathrm{See}$, for example, the Committee for Responsibility, The New York Times (26 February 1967); the Fellowship of Reconciliation (2 February 1967), or the Medical Aid Committee for Vietnam (15 March 1968).

${ }^{76}$ 'Labour members' horror'; 'British M.P.'s protest': The Guardian (23 March 1965).

${ }^{77}$ See, for example, Excerpts from Thant's address at San Francisco and Fedorenko, The New York Times (27 June 1965); Excerpts from Brezhnev Speech at Opening Session of Soviet Party Congress, The New York Times (30 March 1966).

${ }^{78}$ 'Thomas suggests terms for ceasefire', The New York Times (2 April 1965).

${ }^{79}$ See, for example, 'Vietnam chant cuts May Day speeches', The Guardian (3 May 1965); 'On side of humanity', The New York Times (24 October 1965); 'Bombing is backed', The New York Times (3 February 1966); '20 are seized picketing Dow for making napalm', The New York Times (8 October 1966).

${ }^{80} 9$ seize and burn 600 draft files', The New York Times (18 May 1968); 'U.S. visitors back Cambodia charge', The New York Times (10 August 1966); 'Three messages from South Vietnam', The New York Times (9 April 1967).

${ }^{81}$ See, for example, 'Terror at Trang Bang', The Guardian (9 June 1972); 'South Vietnamese drop napalm at own troops',

The New York Times (9 June 1972), 'Girl, 9, survives napalm burns', The New York Times (11 June 1972).

${ }^{82}$ For example, in the war between Ethiopia and Eritrea and in the Western Sahara conflict. 

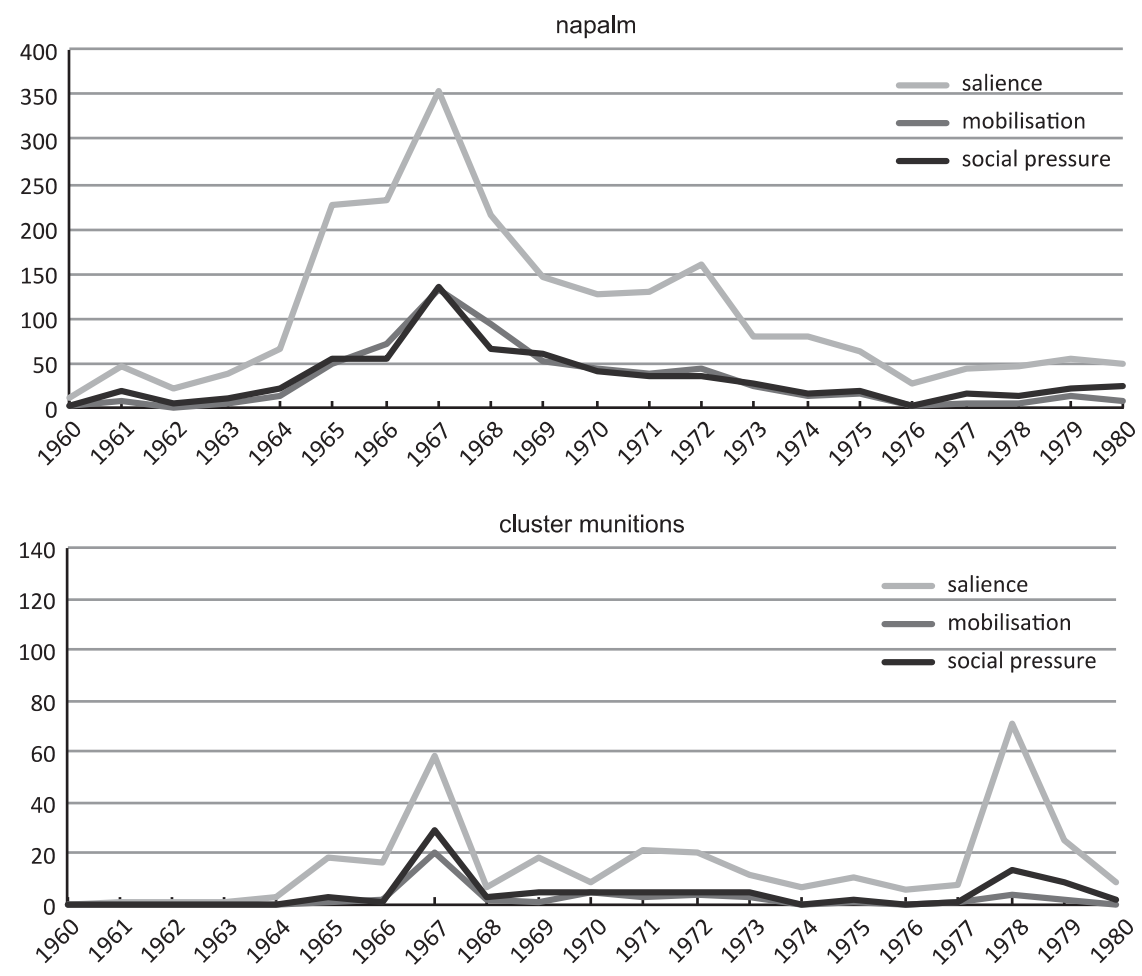

Figure 4. Public salience, mobilisation, and social pressure in coded segments per year (1960-80).

In contrast, the cluster munitions issue never achieved the attention threshold necessary to take off, despite a moderate increase in salience during the Vietnam War and a short-lived peak in 1967. The components of the information stream that made napalm salient were largely absent here. Cluster munitions were never mentioned in the context of the anti-war demonstrations, ${ }^{83}$ and they were neither mentioned in regular war reporting, nor were there articles of other symbolic anti-war actions featuring cluster munitions. The issue's highest salience peak in 1978 also was not enough to establish CM as an issue, as it was linked to one single event (an export scandal related to the US supply of cluster munitions to Israel, which the latter had used against civilian targets in Lebanon), and lacked follow-up events, which would have sustained the attention. While less conspicuous due to the low issue salience, the case of cluster munitions nevertheless supports the finding that mobilisation and social pressure require a certain degree of salience: the issue was lowly salient for about two years before mobilisation and social pressure set in.

These observations support the general expectation that salience matters for the emergence and non-emergence of norms: The issue with a consistently higher salience emerged as a norm, the issue with a lower salience did not. Also, both expectations regarding sequence were confirmed. First, napalm, which had already been an issue during the Korean War, easily recaptured the public's attention during the Vietnam War. ${ }^{84}$ In contrast, cluster munitions struggled to

\footnotetext{
${ }^{83}$ But the protests against the cluster munitions producer Honeywell were mentioned at least few times. See, for example, 'War foes adopt business tactic', The New York Times (28 December 1969).

${ }^{84}$ This happened, interestingly enough, almost without any references to the weapon's use in the Korean War. This points to the impact of tacit knowledge that napalm's salience in the Korean War had created - while not directly observable, its reactivation helped to attract attention to napalm in the Vietnam War. On the limits of observability of mechanisms (such as reactivation of previously salient issues), see James Mahoney, 'Review - beyond correlational analysis: Recent innovations in
} 
come up as a new issue. The anti-war mobilisation and the anti-US criticism spilled over to both issues, but they did so to napalm to a much larger extent. This indicates that the cascade effect also applies to mobilisation and social pressure - not only does an issue's previous salience make it easier for an issue to become salient again, but it also accelerates mobilisation and social pressure, in particular, if both had occurred to a certain extent in the past. Second, in both cases, issue salience preceded mobilisation and social pressure. However, it remains puzzling why napalm's mobilising effect was that much higher. In the following section, I analyse how the framing of the weapons contributes to the explanation.

\section{Framing}

The represented practices of use of both weapons were similar (Table 3). Napalm and cluster munitions were most strongly associated with the same big conflict (the Vietnam War) and the same major users (the US and Israel). In both cases, the majority of mentioned targets were military, but the majority of mentioned victims were civilian. While these categories were similarly salient within the respective discourses, the absolute numbers of corresponding codings varied considerably between the two cases. For example, napalm was mentioned in the context of the Vietnam War almost ten times as often as cluster munitions, ${ }^{85}$ and was associated with attacks against civilian targets as well as with civilian victims about seven times as often.

To stigmatise the weapons, a set of similar attributes was used, but the stigmatising framing of cluster munitions was more obscure and much less salient than the stigmatising framing of napalm. There was an overlap of stigmatising attributes attached frequently to both weapons: In the public discourse, 'death', 'injury', 'children', and 'destructive' were among them. In the institutional discourse, again 'death' and 'injury', but also 'indiscriminate' and 'causing unnecessary suffering' were attached frequently to both weapons, which demonstrates that both cluster munitions and napalm were perceived to conflict with respective IHL principles.

Four important differences are to be mentioned here: First, the framing of napalm revealed how this weapon caused destruction (namely by associating it with fire and burn injuries), but the framing of cluster munitions did not - both a pendant to fire and mentions of specific injuries lacked. ${ }^{86}$ Second, the association of napalm with fire stimulated another attribute, which, however, was ascribed to cluster munitions only twice: fear. This fear, which is suggested to be rooted in different sources, ${ }^{87}$ had a powerful stigmatising effect: 'People have this thing about being burned to death'. ${ }^{88}$ Third, the shares of stigmatising speech acts were higher for napalm by 16 percentage points in the public discourse, and by 9 percentage points in the institutional discourse. In the latter, stigmatising speech acts clearly prevailed with a share of 80 per cent in the case of napalm, and with a share of 71 per cent in the case of cluster munitions, while in both public discourses, stigmatising speech acts constituted less than 50 per cent. Fourth, the differences in absolute numbers - and thus, in the salience of specific frames - were immense: Main attributes, such as death and children, were attached to napalm up to 11 times as often as to cluster munitions; and the overall number of stigmatising attributes was six times higher in the

theory and method', Sociological Forum, 16:3 (2001), p. 581; Andrew Bennett, 'Case study methods: Design, use, and comparative advantages', in Detlef F. Sprinz and Yael Wolinsky-Namias (eds), Models, Numbers, and Cases: Methods for Studying International Relations (Ann Arbor, Michigan: University of Michigan Press, 2004), p. 35; Mario Bunge, 'How does it work? The search for explanatory mechanisms', Philosophy of the Social Sciences, 34:2 (2004), p. 200.

${ }^{85}$ An association that has endured until today; see Keith Beattie, The Scar That Binds: American Culture and the Vietnam War (New York and London: New York University Press, 1998), p. 12.

${ }^{86}$ For a similar proposition, see Prokosch, The Technology of Killing, pp. 91, 98; Borrie, Unacceptable Harm, p. XVI.

${ }^{87}$ Such as the ability of everyone to imagine vividly how painful burning is (in particular, as most people have experienced at least light burns at some point), cultural transmission, or even some inherent human dread of flames. See John Wyndham Mountcastle, Flame on! US Incendiary Weapons 1918-1945 (Shippensburg, PA: White Mane Books, 1999), p. 1; Neer, Napalm, p. 16.

${ }^{88}$ Neer, Napalm, p. 111 , quoting a US pilot. 
Table 3. Framing. Aggregated data from media and institutional documents. ()= per cent, distribution between the cases; ()$^{*}=$ per cent, distribution within the case.

\begin{tabular}{|c|c|c|}
\hline Codings & Cluster munitions & Napalm \\
\hline Practices & $959(12)$ & $6,874(88)$ \\
\hline Conflicts & $340(11)$ & $2,642(89)$ \\
\hline Different conflicts & 20 & 47 \\
\hline Top conflicts & $\begin{array}{l}\text { Vietnam War, } 143(42)^{\star} \\
\text { the Second World War, } 62(18)^{\star} \\
\text { Israeli-Lebanese Conflict, } 47(14)^{\star}\end{array}$ & $\begin{array}{l}\text { Vietnam War, 1,304 }(49)^{\star} \\
\text { Korean War, } 797(30)^{\star} \\
\text { Indochinese War, } 71(3)^{\star}\end{array}$ \\
\hline Users & $357(13)$ & $2,309(87)$ \\
\hline Different users & 22 & 49 \\
\hline Top users & $\begin{array}{l}\text { US, } 219(61)^{\star} \\
\text { Israel, } 56(16)^{\star} \\
\text { UK, } 18(5)^{\star} \\
\text { Ethiopia, } 13(4)^{\star} \\
\text { Republic of Vietnam, } 6(2)^{\star}\end{array}$ & $\begin{array}{l}\text { US, } 1,510(65)^{\star} \\
\text { Israel, } 134(6)^{\star} \\
\text { France, } 115(5)^{\star} \\
\text { UN, } 96(4)^{\star} \\
\text { Republic of Vietnam, } 81(4)^{*}\end{array}$ \\
\hline Targets & $205(13)$ & $1,394(87)$ \\
\hline -military targets & $132(64)^{*}$ & $829(59)^{*}$ \\
\hline -civilian targets & $65(32)^{*}$ & $421(30)^{\star}$ \\
\hline -dual-use targets & $8(4)^{*}$ & $144(10)^{*}$ \\
\hline victims & $57(10)$ & $529(90)$ \\
\hline -military victims & $12(21)^{\star}$ & $161(30)^{*}$ \\
\hline -civilian victims & $44(77)^{\star}$ & $320(61)^{\star}$ \\
\hline -unspecified & $1(2)^{\star}$ & $48(9)^{\star}$ \\
\hline stigmatising speech acts & $226(45)^{\star}(10)$ & $2,129(53)^{*}(90)$ \\
\hline -public discourse & $134(30)^{*}(8)$ & $1,506(46)^{*}(92)$ \\
\hline -institutional discourse & $92(71)^{*}(13)$ & $623(80)^{\star}(87)$ \\
\hline stigmatising attributes & $381(15)$ & $2,214(85)$ \\
\hline $\begin{array}{l}\text { top stigmatising } \\
\text { attributes }\end{array}$ & $\begin{array}{l}\text { anti-personnel, } 56(15)^{\star} \\
\text { fragments, } 39(10)^{\star} \\
\text { indiscriminate, } 30(8)^{\star} \\
\text { area effect, } 27(7)^{\star} \\
\text { death, } 26(7)^{\star} \\
\text { arms trade, } 24(6)^{\star} \\
\text { injury, } 23(6)^{\star} \\
\text { unnecessary suffering, } 18(5)^{\star} \\
\text { children, } 18(5)^{\star} \\
\text { bomblets, } 17(4)^{\star}\end{array}$ & $\begin{array}{l}\text { Fire, } 430(19)^{\star} \\
\text { death, } 274(12)^{\star} \\
\text { injury, } 262(12)^{\star} \\
\text { children, } 213(9)^{\star} \\
\text { indiscriminate, } 155(7)^{\star} \\
\text { abhorrent, } 119(5)^{\star} \\
\text { unnecessary suffering, } 107(5)^{\star} \\
\text { fear, } 78(4)^{\star} \\
\text { destructive, } 73(3)^{\star} \\
\text { inacceptable, } 64(3)^{\star}\end{array}$ \\
\hline Affects and injuries & $21(5)$ & $403(95)$ \\
\hline Top injuries and effects & $\begin{array}{l}\text { high mortality, } 6(29)^{\star} \\
\text { pain, } 3(14)^{\star} \\
\text { difficult medical treatment, } 3(14)^{\star} \\
\text { bodily harm, painful death, suffocation, } 2 \\
(10)^{\star} \text { each } \\
\text { complicated rehabilitation, psychological } \\
\text { trauma, serious injuries, } 1(5)^{\star} \text { each }\end{array}$ & $\begin{array}{l}\text { burns, } 248(62)^{\star} \\
\text { serious injuries, } 27(7)^{\star} \\
\text { bodily harm, } 25(6)^{\star} \\
\text { pain, } 25(6)^{\star} \\
\text { difficult medical treatment, } 22(5)^{\star} \\
\text { high mortality rate, complicated } \\
\text { rehabilitation, psychological trauma, } \\
\text { suffocation, painful death, } 6-18 \text { times } \\
(1-4)^{\star} \text { each }\end{array}$ \\
\hline Weapons references & $257(13)$ & $1,693(87)$ \\
\hline -conventional weapons & $220(86)^{*}$ & $1,275(75)^{*}$ \\
\hline$-W M D$ & $37(14)^{\star}$ & $418(25)^{\star}$ \\
\hline normative references & $73(10)$ & $679(90)$ \\
\hline -IHL references & $50(68)^{\star}$ & $377(56)^{*}$ \\
\hline -moral values & $15(21)^{*}$ & $211(31)^{*}$ \\
\hline -other norms & $8(11)^{\star}$ & $91(13)^{\star}$ \\
\hline
\end{tabular}

napalm than in the cluster munitions case. Napalm-related stigmatising speech acts exceeded cluster munitions-related speech acts by factor 11 in the public discourse, and by factor 7 in the institutional discourse.

Both weapons were embedded in similar normative frameworks, but the strength of this embeddedness varied. The association with conventional weapons was strong in both cases, but 
in the napalm discourse, the share of weapons of mass destruction (WMD) references was by ten percentage points higher than in the cluster munitions discourse. In absolute numbers, WMD references in the napalm discourse exceeded WMD references in the cluster munitions discourse by factor 10 . As to normative references, IHL was the most frequent grafting resource for both napalm and cluster munitions, but the absolute number of normative references was seven times higher in the napalm discourse.

These results demonstrate that framing and salience should be treated as complementary rather than as competing explanations. On the one hand, the stigmatisation of cluster munitions lacked some important aspects, which explains in part why the issue had such weak mobilising effects and did not become salient. On the other hand, cluster munitions weapons were being stigmatised, but their framing was almost invisible and not present in the public conscience, whereas the framing of napalm had reached the public. If the issue as such had caught more attention, its stigmatising frames would have become more salient, too.

\section{Norm entrepreneurs and problem adoption}

Two actors qualify as norm entrepreneurs for the cases in question, namely the ICRC and the United Nations Secretaries-General (UNSG). The ICRC's mandate to serve as the 'guardian of international humanitarian law' ${ }^{89}$ as well as its prominence among (humanitarian) arms control actors qualify the organisation as a gatekeeper. ${ }^{90}$ The UNSGs, addition to their role as chief administrators, serve as normative authorities by using their symbolic and representative power to support the creation and implementation of global norms. ${ }^{91}$ The commitment of the ICRC and the UNSGs to the two norms in question varied. The ICRC acted as a norm entrepreneur for both napalm and cluster munitions; the UNSGs acted as norm entrepreneurs for napalm, but neglected cluster munitions. Does salience explain the variance in problem adoption?

Problem adoption by the ICRC reflected the varying levels of salience between the issues and over time. After the Korean War, during which only napalm had gained salience, the ICRC, too, had turned its attention to napalm only: In 1956, it issued the 'Draft Rules for the Limitation of the Dangers Incurred by the Civilian Population in the Time of War', where in Article 14, incendiary weapons and delayed-action weapons were the only conventional weapons proposed for prohibition. After cluster munitions had gained at least some salience during the Vietnam War, the ICRC tasked a group of governmental experts to examine the conformity of certain conventional weapons, including napalm and cluster munitions, with IHL. Eventually, the ICRC set both weapons on the agenda of the Ad hoc Committee of the CDDH. ${ }^{92}$

The UNSGs, in contrast, consequently focused on the salient issue, napalm, and ignored cluster munitions. In 1970, Secretary-General U Thant issued a report on human rights in armed conflicts, which called upon states to prohibit or restrict certain means of warfare, namely weapons of mass destruction (WMD) and napalm. ${ }^{93}$ His second report, issued in 1972, was devoted solely to napalm and stressed the necessity of prohibitions or restrictions on its use. ${ }^{94}$ The next report, issued by U Thant's successor Kurt Waldheim in 1976, dealt with all weapons discussed in the Ad hoc Committee, but its title singled out incendiary weapons. ${ }^{95}$

\footnotetext{
${ }^{89}$ Self-characterisation, available at: $\{$ https://www.icrc.org/eng/resources/documents/misc/about-the-icrc-311298.htm\}.

${ }^{90}$ Carpenter, 'Vetting the advocacy agenda', pp. 80-1.

${ }^{91}$ Ian Johnstone, 'The role of the UN Secretary-General: the power of persuasion based on law', Global Governance, 9:4 (2003), pp. 451-2; Daisuke Madokoro, 'How the United Nations Secretary-General promotes international norms', Global Responsibility to Protect, 7:1 (2015), p. 36.

${ }^{92}$ Kalshoven, 'Conference', pp. 78-80.

${ }^{93}$ Report of the Secretary-General, A/8052, 'Respect for Human Rights in Armed Conflict', 18 September 1970, p. 115.

${ }^{94}$ Report of the Secretary-General, A/8803, 'Napalm and Other Incendiary Weapons and All Aspects of Their Possible Use', 9 October 1972.

${ }^{95}$ Report of the Secretary-General, A/31/146, 'Incendiary and Other Specific Conventional Weapons Which May Be the Subject of Prohibitions or Restrictions of Use for Humanitarian Reasons', 10 September 1976.
} 
The differences between the ICRC and the UNSGs have two implications for the relationship between issue salience and problem adoption. First, the ICRC was less affected by issue salience in its selection decisions than the UNSGs. The ICRC, too, stated that it tried to mirror the 'global public opinion' with its efforts, ${ }^{96}$ but in addition, the organisation had systematically considered potentially inhumane weapons and made deliberate choices. The UNSGs, however, considered it as within the UN mandate to reflect the public spirit and thus picked up the issue that had figured prominently in public attention. Second, the problem adoption by the norm entrepreneurs affected issue salience in the negotiations in the respective institution, as the following section shows.

\section{Institutional salience, social pressure, and norm emergence}

The institutional negotiations evolved in two sequences: The first round took place in the Ad Hoc Committee from 1974 to 1977; the second in the UNCCW from 1978-80. In the Ad Hoc Committee, a group of seven like-minded states, led by Sweden and including Egypt, Mexico, Norway, Sudan, Switzerland, and Yugoslavia, initially had pushed for bans on both napalm and cluster munitions. This had an effect on issue salience: In the first session in Lucerne, cluster munitions were almost ignored, and the attention devoted to napalm exceeded the attention devoted to cluster munitions by factor 5.8. But in the second session, the attention to the latter rose considerably, and the salience gap narrowed to 2.6 (Figure 5 and Table 5).

In the Lugano session in 1976, however, the group's commitment to cluster munitions dissipated. The proposal on cluster munitions had met with resistance, and the discussion quickly centred on issues with greater potential for agreement, of which napalm was one. ${ }^{97}$ Consequently, napalm's salience increased by more than 50 per cent, while the salience of cluster munitions slightly declined; the salience gap widened again to 4.4. Eventually, the majority agreed that restrictions on incendiary weapons - and on landmines and undetectable fragments, but not on cluster munitions - were needed, but since the delegates could not agree on any specifics, they called upon the UNGA to conduct another conference. ${ }^{98}$

The common ground that began to emerge in the Ad Hoc Committee solidified at the UNCCW. During the Preparatory Conference, the like-minded group, which now included some new members and all previous members with the exception of Norway, continued to demand a prohibition of incendiary weapons, but not on cluster munitions. ${ }^{99}$ Solely Mexico had not given up on the issue completely and submitted a draft clause including a prohibition on cluster munitions as well as a draft of an umbrella treaty, which would include a protocol on cluster munitions. ${ }^{100}$ But this effort was futile: Cluster munitions did not gain ground in the debate, and neither an informal plenary nor a working group were devoted to them. ${ }^{101}$ Consequently, no draft protocol on cluster munitions was submitted to the main conference that began six months later - but several draft protocols on napalm. ${ }^{102}$ In the ensuing negotiations, the delegates were

\footnotetext{
${ }^{96}$ ICRC, 'Reaffirmation and Development of the Laws and Customs Applicable in Armed Conflicts. Report Submitted By the International Committee of the Red Cross' (1969), available at: \{http://www.loc.gov/rr/frd/Military_Law/pdf/RC-Reportreaffirm-development-1969.pdf\}, pp. 48, 60-1.

${ }^{97}$ Prokosch, The Technology of Killing, pp. 155-6; Mathews, '1980 Convention', pp. 994-5.

${ }^{98}$ Sandoz, 'New step', p. 6; W. Hays Parks, 'The protocol on incendiary weapons', International Review of the Red Cross, 279 (1990), p. 538.

${ }^{99}$ The new members that joined the like-minded group were Austria, Ghana, Jamaica, Romania, Togo, Venezuela, and Zaire. The group submitted Draft Proposal A; proposal B by Norway and Denmark suggested prohibiting the use of incendiary weapons against civilians and civilian targets, and, with some exceptions, against military personnel. Proposals K, M, O by Australia, the Netherlands and Indonesia also included much weaker norms than the proposal by the like-minded group. Report of the Preparatory Conference, A/CONF.95/3, 25.5.1979, Annex I.

${ }^{100}$ Report of the Preparatory Conference, A/CONF.95/3, 25 May 1979, Annex I F.

${ }^{101}$ Report of the Preparatory Conference, A/CONF.95/3, 25 May 1979, p. 12.

${ }^{102}$ Report of the Conference to the General Assembly, A/CONF.95/8, 8 January 1979.
} 


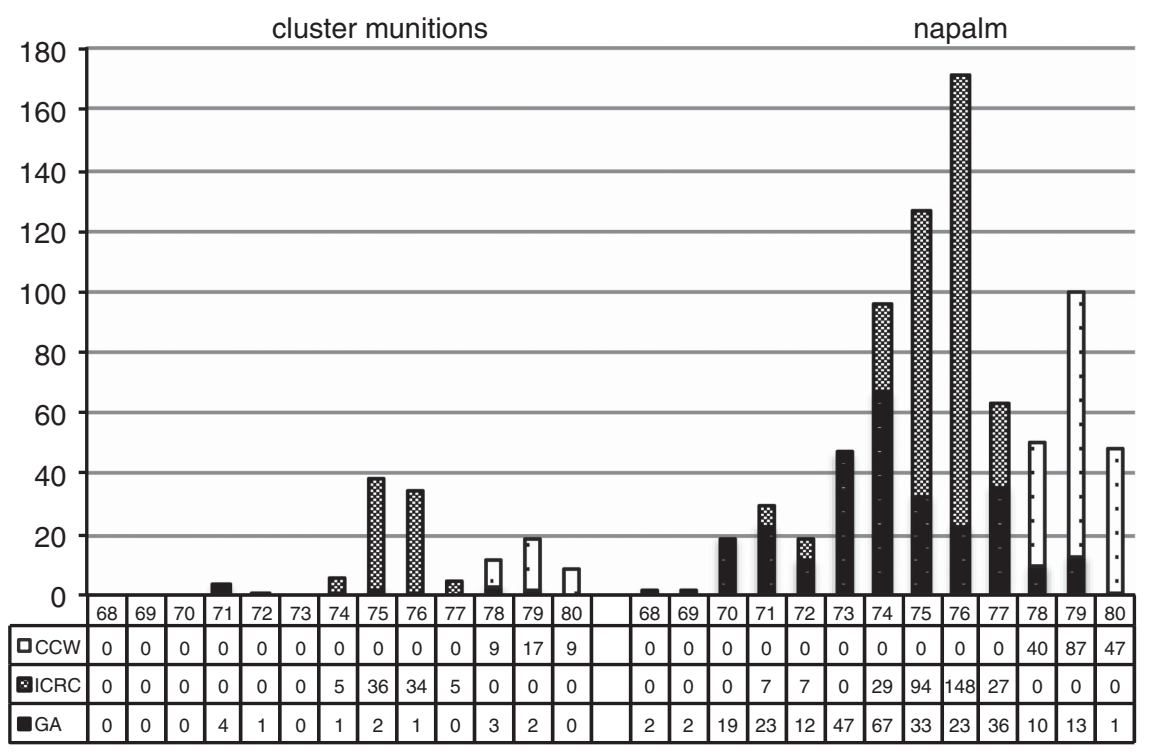

Figure 5. Institutional salience of cluster munitions and napalm in coded segments per year (1968-80).

fully occupied with the unresolved specifics of the tabled proposals, with no capacities left to revive proposals that had slipped off the agenda already, among them the one on cluster munitions.

What role did social pressure play for these outcomes and how was it exercised? There was almost no public social pressure related to cluster munitions at the time of the conferences. But it had also dropped considerably for napalm: the Vietnam War was over, and so was the shaming of its users; the international negotiations received very little public attention. ${ }^{103}$ In the institutional discourse, shaming was rare with regard to both weapons, but it still occurred five times more frequently for napalm (Table 4). Also, shaming was limited to UNGA debates - it almost never occurred in the ICRC and the CCW negotiations, which indicates that shaming is a publicoriented strategy, not necessarily fitting into a diplomatic environment.

And yet, the effects of social pressure were more persistent than its actual exercise. The public discussion had calmed down, but the delegates felt under pressure to achieve results, at least with regard to napalm. ${ }^{104}$ Speakers emphasised the public revulsion towards napalm and the public expectation that the conferences would achieve results. The condemnation of napalm by the international political community, which had begun in the early 1970s with reports of the UNSGs and UNGA debates and resolutions, was another source of pressure (Table 6).

Both UN institutions had largely ignored cluster munitions in their efforts, but kept criticising the use of incendiary weapons and demanding an international prohibition. The salience of napalm in UNGA debates exceeded the salience of cluster munitions by factor 20.6. The perceptions of the delegates matched this imbalance: In the ICRC negotiations and in the CCW, the delegates regularly referred to UNSG reports and UNGA discussions when discussing napalm but almost never when discussing cluster munitions. Also, while abstaining from shaming, the ICRC and CCW conference participants built momentum through expressing support for the

\footnotetext{
${ }^{103}$ The SG's first report on napalm and the related GA resolution were mentioned in one article, and discussed at length in a second one. The ICRC negotiations were mentioned in one article; the UNCCW in two, both of which reported that the conference ended.

${ }^{104}$ Neer, Napalm, p. 183; Frits Kalshoven, 'Conventional weaponry: the law from St. Petersbrug to Lucerne and beyond', in Frits Kalshoven (ed.), Reflections on the Law of War (Leiden and Boston: Martinus Nijhoff, 2007), p. 388; W. Hays Parks, 'Means and methods of warfare', George Washington International Law Review, 38:3 (2006), p. 521.
} 
Table 4. Salience, stigmatisation, and social pressure in the institutional process. ()=percent, distribution between the cases; ( ${ }^{\star \star}$ CCW and ICRC only.

\begin{tabular}{lcc}
\hline Codings & Cluster munitions & Napalm \\
\hline Salience & $130(14)$ & $774(86)$ \\
-UNGA & $14(5)$ & $288(95)$ \\
-ICRC & $81(21)$ & $312(79)$ \\
-CCW & $35(17)$ & $174(83)$ \\
Stigmatising speech acts & $92(13)$ & $623(87)$ \\
-UNGA & $14(5)$ & $250(95)$ \\
-ICRC & $56(19)$ & $238(81)$ \\
-CCW & $22(14)$ & $135(86)$ \\
social pressure & $11(9)$ & $117(91)$ \\
-shaming & $9(16)$ & $47(84)$ \\
-UNGA or UNSG & $2(4)^{\star *}$ & $49(96)^{\star \star}$ \\
-public opinion & $0(0)^{\star *}$ & $21(100)^{\star *}$ \\
\hline
\end{tabular}

Table 5. Examples of statements referring to public opinion and UNGA resolutions.

'It should be borne in mind, however, that international public opinion expected the Conference to take a stand on the side of humanitarian law', Madagascar, CDDH/IV/SR.IO, 19 February 1975.

'Particular attention should be paid to the question of incendiary weapons, the prohibition of which ... was urgently demanded by public opinion', Finland, CDDH/IV/SR.17, 14 March 1975.

'It was ... important, by prohibiting their use against the civilian population, to allay the fears of the public', Australia, A/CONF.95/PREP.CONF./Il/SR.23, 6 April 1979.

'Should not an attempt be made to ban incendiary weapons ... considered by international public opinion to be of the most reprehensible kind', Sweden, A/CONF.95/PREP.CONF./l/SR.4, 31 August 1978.

'No category of conventional weapons had evoked greater public revulsion than incendiary weapons, including napalm, and numerous resolutions, seeking to prohibit or restrict their use had been adopted by the United Nations', African National Congress for South Africa, A/CONF.95/PREP.CONF./l/SR.9, 8 September 1978.

'An agreement on the prohibition or restriction of the use of some of those weapons would meet the wishes expressed by the General Assembly in resolution 32/152', Zaire, A/CONF.95/PREP.CONF./l/SR.8, 6 September 1978.

norms in plenary meetings - again, with a huge imbalance towards napalm, in terms of the breadth and intensity of support.

Eventually, the adoption of Protocol III hinged on the United States and the Soviet Union. The US were reluctant to agree - and the USSR conditioned their approval on the approval of the US. In the final days of the conference, the pressure on both worked out: The echo of Vietnam War protests ${ }^{105}$ and the persistence of the like-minded group 'shamed the U.S., and maybe the Soviet Union too, into a concession'. ${ }^{106}$ When the US agreed, so did the USSR. ${ }^{107}$ As delegates reported later, for some, to prohibit or to regulate incendiary weapons was a 'dictate of the public conscience', 108 and the 'raison d'etre for the $\mathrm{CCW}^{\text {'109 }}$ - 'any agreement on conventional weapons which did not include a Protocol on incendiary weapons would have the distressing appearance of a fire-brigade which had forgotten to bring the hose-pipe. ${ }^{110}$ The conference closed with a norm against napalm. ${ }^{111}$

\footnotetext{
${ }^{105}$ Prokosch, The Technology of Killing, p. 170.

${ }^{106 ' O f}$ toys and tragedies', The Guardian (8 October 1980).

${ }^{107}$ Howard S. Levie, 'Some recent developments in the law of war', German Yearbook of International Law, Volume 25 1983), p. 271; Kalshoven, 'Conventional weaponry', p. 392; Carvin, 'Conventional thinking?', p. 58.

${ }^{108}$ Kalshoven, 'Conventional weaponry', p. 388.

${ }^{109}$ Parks, 'Means and methods of warfare', p. 521.

${ }^{110}$ Sandoz, 'New step', p. 13.

${ }^{111}$ The high salience of the napalm issue before the adoption of the CCW did not translate into high ratification numbers of the Protocol on Incendiary Weapons - on the contrary, the ratification process never took off, and the treaty has only 115 members today (as of April 2018). This sluggish process, however, does correspond to the low salience of the napalm issue in the decades since the Vietnam War; it seems that the napalm issue, after having completed the first attention cycle, did not enter another one. The causes of the slow universalisation of this treaty are as much an interesting question for further research as is the relationship between pre- and post-treaty adoption salience, universalisation, and ratification campaigns.
} 


\section{Synthesis: Explaining the emergence of the norm against napalm and the non-emergence of the norm against cluster munitions}

The emergence of the norm against napalm and the non-emergence of the norm against cluster munitions can be explained as a path-dependent process, in which initial discrepancies in salience grew further and became decisive through influencing the visibility of framing, mobilisation, and social pressure. Cluster munitions enjoyed some attention for the first time before napalm did, namely in 1945, but their use did not spur any criticism. Timing and context explain why. After all the cruelties of the Second World War, the public was numb; moreover, ending this war had become the overriding concern trumping humanitarian concerns about means and methods of warfare. Furthermore, after years of bombing cities, cluster munitions did not stand out as a particular bomb. When they did - to a certain degree - more than twenty years later, there was no attentional or mobilising precedent to adhere to, so the attention they received was still low, and their framing, despite conveying that the weapons were destructive and indiscriminate, was lacking concreteness as well as visibility. In turn, mobilisation around these weapons as well as social pressure on their users remained low (Figure 6).

For napalm, the Korean War in the early 1950s became a critical juncture. Then, the emotional and legal reprocessing of the Second World War had begun, the new international system

Table 6. UN resolutions referring to napalm and cluster munitions.

\begin{tabular}{|c|c|c|}
\hline Resolution & Incendiary weapons & Cluster munitions \\
\hline $\begin{array}{l}\text { Resolution XXIII, 'Human Rights in Armed } \\
\text { Conflicts', International Conference on } \\
\text { Human Rights, } 12 \text { May } 1968\end{array}$ & mentioned & / \\
\hline Resolution 2852 (XXVI), 20 December 1971 & mentioned alongside with WMD & / \\
\hline Resolution 2932 (XXVII), 29 November 1972 & dealt with in a whole section & / \\
\hline Resolution 3076 (XXVIII), 6 December 1973 & subject of the whole resolution & / \\
\hline Resolution 3252 (XXIX), 9 December 1974 & subject of the whole resolution & 1 \\
\hline Resolution 3464 (XXX), 11 December 1975 & subject of the whole resolution & / \\
\hline Resolutions 31/64, 19 December 1976 & mentioned in the title & $\begin{array}{l}\text { mentioned among other specific } \\
\text { conventional weapons }\end{array}$ \\
\hline Resolution 32/152, 9 December 1977 & mentioned in the title & $\begin{array}{l}\text { mentioned among other specific } \\
\text { conventional weapons }\end{array}$ \\
\hline
\end{tabular}

\section{CLUSTER MUNITIONS}

framing: blurred, conventional

low salience in the Korean War $\longrightarrow$ low salience in the Vietnam War

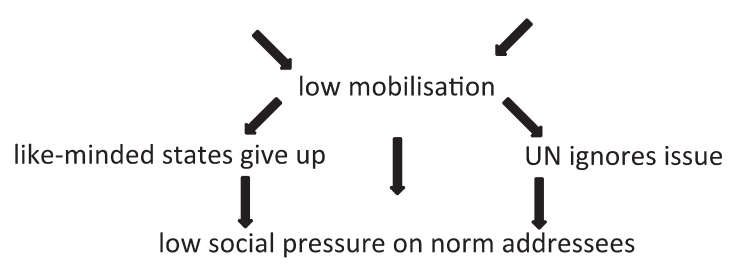

non-emergence of the anti-cluster munitions norm

Figure 6 . The non-emergence of the norm against cluster munitions. 


\section{NAPALM}

framing: fire, fear, abhorrence, WMD

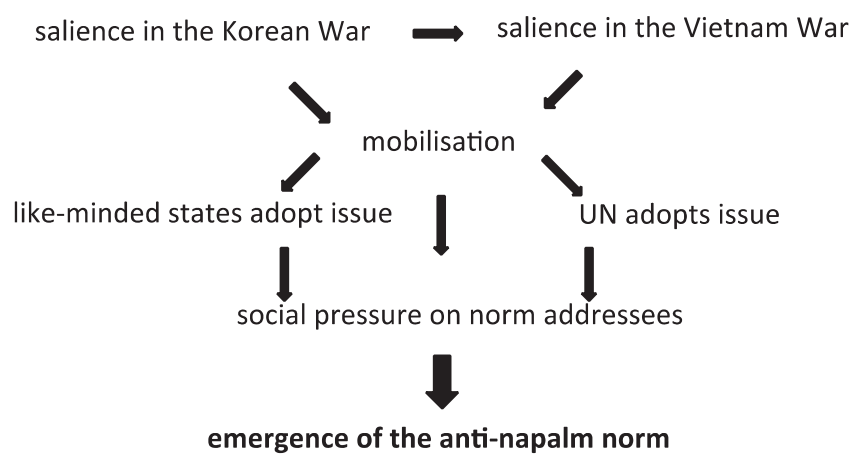

Figure 7. The emergence of the norm against napalm.

was being institutionalised, and the public became increasingly sensitised to humanitarian and human rights issues, of which the atomic bombings of Hiroshima and Nagasaki were one. These factors drew attention to methods and means of warfare and thus, to the use of napalm.

This first salience peak of the napalm issue facilitated the recapturing and cascading of public attention during the Vietnam War. At the same time, the controversy over the conflict as such spilled over to the weapon closely associated with this conflict. In a self-sustaining dynamic, the criticism of the Vietnam War and the criticism of napalm mutually reinforced each other. The stigmatisation of napalm particularly benefited from two aspects: First, the discursive inseparability of napalm, fire, and burns triggered widespread fear. ${ }^{12}$ Second, despite being considered a conventional weapon, napalm was strongly linked to WMD - not so much because its effects were comparable to the effects of any of the three categories of WMD, but rather because the abhorrence it caused was similar to the abhorrence caused by WMD. (Figure 7)

\section{Conclusion}

This article argued that salience explains norm emergence through its impact on four other factors, namely on norm entrepreneurs, framing, mobilisation, and social pressure. Napalm, the issue with a consistently higher salience, emerged as a norm - cluster munitions, the issue with a lower salience, did not. Salience appears as a necessary condition for other factors: rises in mobilisation and social pressure as well as issue adoption by institutional norm entrepreneurs were preceded by salience peeks; the effectiveness of similar framings varied depending on their visibility.

As I borrowed the concept of salience from other established disciplines, namely communication and media research, a huge amount of previous theoretical and empirical work supports the general claim of this study that issue salience is a relevant factor in explaining political outcomes. But how generalisable are my findings with regard to research on international norms? Since the emergence of norms may be very different and contingent upon many factors, I am neither suggesting that salience is a sufficient explanation nor that it matters in all cases. But, concluding from the cases analysed here, I consider the findings to be potentially applicable to norm-setting processes displaying following features: bottom-up processes initiated outside of governmental policymaking spheres by transnational or institutional norm entrepreneurs; processes promoting norms that are likely to be met with governmental resistance; and processes

\footnotetext{
${ }^{112}$ Mountcastle, Flame on! US Incendiary Weapons 1918-1945, p. 1.
} 
promoting rather non-technical norms with primarily ethical implications, which have the potential to ignite public opinion.

In addition to a better understanding of individual cases, further applications of the model suggested here promise to advance the theoretical understanding of the interplay of salience and other factors relevant for norm emergence. In my analysis, I bracketed the effects of mobilisation, social pressure, issue adoption, and framing on salience, which was sufficient to explain the cases of interest here. Yet, in other cases, the influence might be mutual, or the other factors might precede salience. This invites formulations of other models as much as further specification of the conditions under which the respective models apply.

Acknowledgements. For excellent comments on earlier versions of this article, I am grateful to Charli Carpenter, Caroline Fehl, Marco Fey, Marcel Heires, Catherine Hecht, Carsten Rauch, Niklas Schörnig, the editors of the journal and the three anonymous reviewers. I also thank the participants of the Junior Scholar Symposium at the ISA Annual Convention 2015. Karl Buchacher and Sophie M. Behr provided tremendous research assistance and language editing.

Elvira Rosert is Junior Professor for International Relations at Universität Hamburg and at the Institute for Peace Research and Security Policy. Her research is concerned with the emergence, robustness, and interaction of international norms, mainly in the fields of International Humanitarian Law and Humanitarian Arms Control. She is also studying international organisations, in particular, the United Nations. Her new book on permissive effects and the non-emergence of international norms is forthcoming with Springer VS.

Cite this article: Rosert, E. 2018. Salience and the emergence of international norms: Napalm and cluster munitions in the inhumane weapons convention. Review of International Studies 45: 77-99. doi:10.1017/S0260210518000232 